\title{
Revaluation of 'old' ore mining areas of the Amur River region (Russia)
}

\author{
Viktor Kryukov ${ }^{1 *}$ \\ ${ }^{1}$ Mining Institute of Far eastern branch of Russian Academy of Sciences Khabarovsk, Russia
}

\begin{abstract}
In recent years, highly liquid precious metals have been mined in the Russian Far East. The state fund has no facilities with confirmed reserves. However, there is a real possibility of reviving the 'old' mining areas. Based on the Lower Amur region (Khabarovsk region) the prospects of gold reserves accumulation using 'small' fields (in 50-80-s conception) are considered. It deems new to determine the potential of these facilities from the viewpoint of large-scale mineralization and to involve the territory under consideration in the assessment of the gold-bearing manifestations. 'Reference' deposits were selected and their specific productivity was assessed, which was extended to similar by properties manifestations. Within the Lower Amur region, geological investigations revealed about 300 small deposits and mineral occurrences. 34 objects localized at the clusters of submeridional and sublatitudinal faults intersection, were identified as promising. Basically, the gold-ore blocks were compared with the 'standards': Belogorsky (near-surface), Dyappe (subvolcanic) and Zimovye (hypabyssal). The determining factors were the structural features of mineralization localization, facies conditions, the ores composition and metasomatites, the zonality of ore-metasomatic formations, the erosion of objects and the completeness of hydrothermal processes. The author's assessment is confirmed by the results of exploration works at 15 'small' deposits and ore occurrences, with the transfer of 11 of them to the category of large and medium-sized.
\end{abstract}

\section{Introduction}

The aim of this research is to draw attention to potential revaluation of the so-called ore mining areas due to depletion of the deposits national reserves and mineral occurrences. Revision works necessity should be noted in the known mineral areas whose industrial development has reduced significantly due to mineral resources base depletion [1]. The practice of revaluation of 'small' gold deposits in the Far East confirms such works' necessity and effectiveness. So, over the past decade, about ten gold ore and complex gold-bearing deposits have been transferred from the small reserves category to the large $[2,3]$ in the Amur river Region.

The methodological aspects and results of determining the potential of the 'old' ore mining regions are analyzed on the example of the analysis of the gold content of the Lower

\footnotetext{
*Corresponding author: kryukov-vg@mail.ru
} 
Amur Region. For prognosis evaluation, the researches usually emphasized the prospects of Mnogovershinnoye, Albazinskoye, Agnie-Afanasievskoye, and Belogorskoye deposits [4, $5,7-9]$. The remaining facilities were classified as small by reserves, and as a rule, nonpromising ones. It should be noted that there are no facilities in the exploration practice in the Far East, for which a final evaluation was given during one study cycle. The works on most of the Amur River mineral occurrences in the 20th century ceased after the first cycle, and this served as the basis for assessing the region's as having not high gold content.

\section{Analysis technique}

Methodical technique for revaluation of the potential of 'old' mining areas were developed at the facilities of the Lower Amur Region. The Lower Amur River gold-bearing area with dimensions of $450 \times 250 \mathrm{~km}$, stretched in the submeridional direction, covering the areas of the Amur and Amgun river basins in their lower reaches, as well as Ulban, Usalgin, Gur, Tumnin and Butu. A considerable number of deposits and mineral occurrences have been established within its boundaries: gold-210 (gold-silver, gold-sulphide and polymetallicgold formations), copper and molybdenum - more than 40, secondary quartzites - about 30 , polymetals -7 , tungsten -10 . Belogorskoye, Mnogovershinnoye, Herpuchinskoye, PildaLimuriskoye and Tumninskoye ore-alluvial regions were studied and exploited.

The revaluation includes the following main lines:

- geological-tectonic zoning of the territory;

- selection of standards and justification of their specific productivity;

- comparison of known manifestations and 'small' deposits with the standards;

- the facilities prognosis evaluation.

Geological-tectonic zoning of the territory is based on geological surveys materials Sc. 1: 200000 and Sc. 1:50 000, the results of prospecting and evaluation works and author's observations (study of individual deposits, mineral occurrences, and decoding results). The main metallogenic elements of the structural framework of the Lower Amur Region, according to author's opinion, are the orthogonal system of faults, tectonomagmatic archings and linear disturbances (fig. 1). The noted structures directly control the location of magmatics, metasomatites and ore mineralization. The standards were selected among the most extensively studied facilities.

The choice of standards and the justification of their specific productivity is deemed to be the most difficult task. With the purpose of revaluating the potential of the territory under consideration, the author, starting from 1991, has analyzed the source materials for a significant part of the occurrences: 172 - gold, 28 - copper and copper-molybdenum facilities, 12 - secondary quartzites, 4 - polymetals and tungsten.

Structural diagrams and layouts for the distribution of circum-ore metasomatites, structural-and-facial columns for circum-ore metasomatites were compiled for the standards, taking into account their vertical extent, the degree of erosion in the categories of weak, moderate, medium and substantially eroded bodies was determined, the completeness and degree of completion of the hydrothermal process was determined, as well as specific productivity. To determine the specific productivity, the ratio of reserves approved by the State Committee for Reserves, of industrial categories or proprietary reserves to the area to which these reserves are distributed was established. The productivity of the ore field of the reference facility served as the basis for determining the resources of the correlated mineral occurrences and deposits.

The unifying signs are the confinement to tectonic elements of fairly large blocks of the earth's crust (the metallogenic zone or region grade), the originality of the genetic series of ore-magmatic systems (pre-, syn- and post-intrusive metasomatites associated with specific intrusive complexes), ore-hosting metasomatites, etc. 


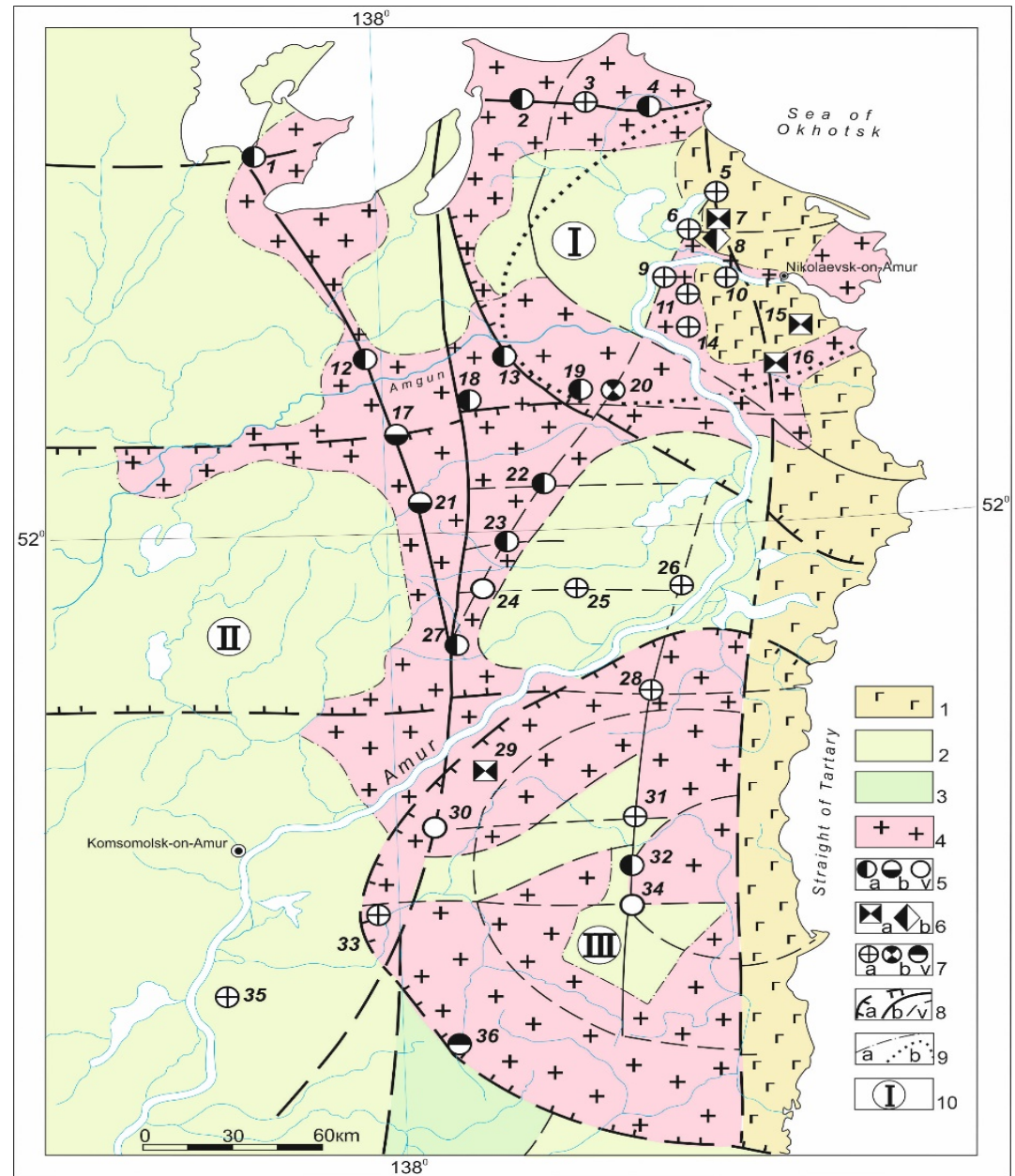

Fig. 1. Metallogenic diagram of the Lower Amur gold-bearing area

1. Basalts, andesites, their tuffs of Paleogene age. 2. Sedimentary complexes of the Early Cretaceous. 3. Paleozoic metamorphic complexes. 4. Areas of Cretaceous and Paleogene magmatics. 5-7. Deposits and mineral occurrences. 5. a) gold-quartz, б) gold-mercurial, в) gold-tungsten. 6. Secondary quartzites a) deposits, б) mineral occurrences. 7. a) porphyritic, б) polymetallic, в) tungsten. 8. Faults. 9. Boundaries of: a) areas, б) Takhtinskoye massif . Ore bodies: 1. Kutynskoye. 2. Manguliyskoye. 3. Mayak. 4. Mnogovershinnoye. 5. Belaya Gora. 6. Blagodatnenskoye. 7. Iskinskoye. 8. Seredochnoye. 9. Kabachinskoye (Sberegatelnoye). 10. Bukhtyanskoye. 11. Tyrskoye. 12. Albazinskoye. 13. Chulbatkanskoye. 14. Dylmenskoye. 15. Krugliy Kamen'. 16. Gryada Kamenistaya. 17. Imskoye. 18. Angochikanskoye. 19. Oktyabrskoye. 20. Chayatynskoye. 21. Bichinskoye-1. 22. PokrovskoTroitskoye. 23. Agnie-Afanasievskoye. 24. Uchaminskoye. 25. Dyappe. 26. Kholanskoye. 27. Delkenskoye. 28. Limonitovoye. 29. Shelekhovskoye. 30. Ezhovoye. 31. Zimovye 32. Levodzhegdagskoye. 33. Poniyskoye. 34. Oemkuyskoye. 35. Malmyzhskoye. 36. Dzhaurskoye.

On these grounds the deposits of the near-surface, subvolcanic and hypabyssal depth facies were separated. The first group is represented by the standard - the Belaya Gora deposit, which is compared with the manifestations, and small deposits of Blagodatnenskoye, Bukhtyanskoye, Dylmenskoye, Kabachinskoe, Limonitovoye, Mayak, Polyanka, Tarakanovskoye. The group of subvolcanic deposits includes the standard of Dyappe, as well as Agnia-Afanasyevskoye, Albazinskoye, Pokrovsko-Troitskoe. The Zimovye reference standard refers to the hypobyssal one, which compares Ledvozhegdagsky, Mnogovershinnoye, Oemka, Uchaminskoye. 


\section{Research results}

Within the area the author distinguishes metallogenic elements (from the north to the south): the Lower Amur metallogenic region, the Evoron-Udylskaya metallogenic zone and the Tumninskaya metallogenic region. The metallogenic regions represent tectonomagmatic archings, while the metallogenic zone - a system of Gorstian- and trough-shaped structures (fig.1). The distribution of intrusive rocks, metasomatites and mineralization within the boundaries of the influence of certain structures, emphasizes the nature of the latter. Thus, the zones of sublatitudinal strike serve as ore-supplying and controlling, while submeridional ones serve as the controlling structures. In this case, the 'step' in the spatial position of the deposits makes 30,60 , less than 15 kilometers. The role of diagonal faults is in ore distribution (ore-distributing structures). Disturbances of orthogonal and diagonal systems, are noted as ore-hosting.

Within the Lower Amur Region, Mnogovershinnoye deposit is exploited (4 - here and further in the parentheses are the objects numbers in fig.1). From Mnogovershinnoye ore cluster to the west, within the sublatitudinal structure, the promising mineral occurrences of Mayakskoye (3), Manguliyskoye (2) and the Kutynskoe deposits (1) are noted. A favorable situation is characteristic of deposits controlled by the ore-distributing structure of the northeastern orientation. Belaya Gora (5), Blagodatnenskoye (6), Kabachinskoe (9), Tyrskoye (11) and Chayatynskoe (20) deposits are in the range of its influence.

As a standard of near-surface deposits, Belaya Gora was chosen, the ore mineralization of which is localized within the lateral apparatus of a large stratovolcano of the Cainozoic age. Mineralization is basically a tubular stockwork and a blanket-like deposit. In the author's opinion, mineralization, confined to ring structures in the headstream of the Kolchanka spring, as well as the bodies of the submeridional and northwestern strike under the alluvial deposits of Belogorskoye and Verkhnyaya, can be of large importance.

The gold reserves of the deposit equal to 24.5 tons (deposit and stockwork). Resources of $\mathrm{P}_{1}$ category -3 tons, and are localized in ore bodies controlled by a sub-latitude structure (the Zayachiy, Kolchanskoye, Levoberezhnoye, Ogorodnoye-1, -2, Pavlovskoye areas). The total area of the proved area is 2.2 square $\mathrm{km}$. The specific productivity, taking into account the transfer of resources into the category of reserves, is $11 \mathrm{t} / \mathrm{km} 2$. The forecasted area includes the proved area, marked sites with resources of category $\mathrm{P}_{1}$, and also the area of the Kolchanka spring basin area (in its headstream), which totally equals to 8.6 square $\mathrm{km}$. Taking into account the parameters of the mentioned structures, the prognosis evaluation of the ore field may equal to more than 100 tons of gold.

In the Evoron-Udylskaya metallogenic zone, the fields are being prepared for development (Dyappe, Polyanka, Chulbatkanskoye, etc.). Pokrovsko-Troitskoye (22), AgniyeAfanasyevskoye (23), Uchaminskoye (24), Delkenskoye (27) deposits are confined to the ore-distributing structure of the northeastern strike are referred to the promising facilities. Besides, three latitudinal-oriented chains of promising mineral occurrences (from north to south) are noted: 1) Imskoye (17), Angochikanskoye (18), Oktyabrskoye (19), Chayatynskoe (20); 2) Bichinskoe-1 (21), Elovoye, Pokrovsko-Troitskoe (22); 3) Uchaminskoe (24), Dyappe (25), Holanskoye (26). In the spatial position of the deposits, a clear regularity is established: the 'step' between them, both in latitude and meridian, is 30 and 60 kilometers.

The Dyeppe deposit is a standard for subvolcanic type. The ore field has an oval shape in plane and dimensions of $4 \times 3.5$ kilometers. The oval is extended in the submeridional direction. Within its limits, 39 ore bodies - zones of mineralization, which have the form of a linear stockwork, have been identified and studied, lens-and rod-shaped, and vein, in the form of relatively isometric blocks of stringer-porphyry mineralization. They are separated into 4 areas: Central, North-West, South-West and Eastern with a total area of about 6.8 
square meters. The most extensively studied is the Central area, drilled by spacing of $20 \times 20$ $\mathrm{m}$. Authorized reserves of the Central area, limited to an area of 0.7 square km, are 7.6 tons, which determines the specific productivity of 11 tons per unit area. The predictable mineralization exceeds 100 tons, localized on an area of 6.8 square $\mathrm{km}$.

For some of the analogs, significant reserves of gold have already been proven: Albazinskoye - 112 tons, Delkenskoye - 42.5 tons, Kutynskoye - 18 tons (table 1).

Tumninskoye metallogenic region is characterized by a rather specific metallogenic profile. An important part is played by alluvial and ore gold ones. Gold alluvial deposits were developed in the first half of the previous century, and since the 1950s, hardrock gold deposits (Oemku) began to be developed. Among the leading commercially valuable minerals of the territory, secondary quartzites should be referred to as a source of aluminum and other components, including gold. The Shelekhovskoye deposit (29) is the most prepared for development. Tungsten mineralization, detected in the central and intermediate zones of the taxon is deemed to be a promising one. Copper-molybdenum-porphyritic bodies and insignificant polymetals occurrences are known within the region. The ore controlling is the fracture of the submeridional strike, traced from the city of Kholan in the basin of the Yai and Jegdag rivers and further to the south into the basins of the Zimovye, Tumnin rivers, and the headwaters of the Gur River. It determines the position of different metals deposits: gold - the Kholanskoe, Levodzhegdagskoye (32), Oemku (33), the porphyritic formations Limonitovoye (28) and Zimovye (31), polymetals. The role of ring disturbances affects the location of secondary quartzites: Shelekhovskoye (29), Salasinskoye, Elovoye, Karginskoye, Pulsinskoye, Bystrinskoye and others. Within the outer ring of the arching, there are also molybdenum-tungsten with gold, Ezhovoye (30), and gold-silver mineral occurrences.

Zimovyinskoye deposit (ore field) is identified as a standard for bodies formed in hypabyssal conditions within the intrusive-dome structure. Within a single framework of sub-meridional zone, 4 areas are differentiated for $5 \mathrm{~km}$ (from the north to the south): Pestroye, Tsokolnoye, Taimen and Zolotonosnoye. Authorized reserves for the Pestroye area of 0.8 square $\mathrm{km}$ (essentially tungsten with gold mineralization) were determined by A.M. Ezheley (2001) as 19.6 thousand tons of tungsten oxide and 2 tons of gold. The results of the Tsokolnoye assessment, having an area of 0.5 square km (gold-tungsten with sulphides mineralization) are distinguished by a higher gold grade, the reserves being equal to 10 tons of gold. Specific productivity for these areas will make 24,000 tons of tungsten oxide and 10 tons of gold. The predictable gold resources for the entire body of about 10 square $\mathrm{km}$. exceed 50 tons, and tungsten oxide - 100 tons. The predictable specific productivity of gold in this type of deposits is 5 tons per $1 \mathrm{sq} . \mathrm{km}$.

High prospects of the Lower Amur region bodies, apart from their favorable structural position, the author assigns to a number of factors:

- the scale and completeness of the processes of circum-ore metasomatism. Thus, at the Pokrovsko-Troitskoye deposit, metasomatic bodies containing mineralization are traced along a strike for $6 \mathrm{~km}$, with outbreak width of about $2.5 \mathrm{~km}$. Similar parameters are characteristic of Agnia-Afanasyevskoye, Dylmenskoye, Diappe, Holanskoye, etc.;

- by wide manifestation of large-scale mineralization. A well-mapped stockwork on the Dyappe field did not attract geologists' attention to the morphology of ore bodies at that time. At the same time, a variety of morphological types is characteristic of other objects. Hardly identifiable columnar or rod-shaped ore bodies deserve a special attention;

- vein systems with a moderate degree of deposits erosion cut are replaced by veindisseminated mineralization or stockwork at the depth of a number of bodies;

- by sufficiently high gold content in metasomatites. For example, at the Dyappe deposit, in a stockwork, tapped by boreholes, it amounted to 3 and $5 \mathrm{~g} / \mathrm{t}$ for a thickness of 7 and $24 \mathrm{~m}$, in metasomatites of Pokrovsko-Troitskoye by channel samples - up to $7 \mathrm{~g} / \mathrm{t}$, in an industrial 
sample weighing more than 21,000 tons from 'unchanged' green and black-colored sedimentary rocks of the Agniye-Afanasyevskoye deposit - $3.17 \mathrm{~g} / \mathrm{t}$;

- underestimation, in 2-2.5 times, of gold content in samples analyzed in the laboratory of the Lower Amur expedition for the period from 1985 to 1989. In the southwestern part of the area, porphyritic-and-gold mineral occurrences are recorded. At one of them, Malmyzhskoye, the works of 2005-2013 not only confirmed the porphyritic type of the body, but also established authorized reserves in the amount of 298 tons of gold and 5.6 million tons of copper. Researchers emphasize the identification of a new, unique deposit [3].

Table 1. The potential of gold ore facilities of the Lower Amur River Region (tons)

\begin{tabular}{|c|c|c|c|c|c|c|}
\hline \multirow[t]{3}{*}{ No } & \multirow{3}{*}{$\begin{array}{l}\text { Deposits and mineral } \\
\text { manifestations }\end{array}$} & \multicolumn{4}{|c|}{ Potential } & \multirow{3}{*}{$\begin{array}{l}\text { Author's } \\
\text { assess- } \\
\text { ment, } \\
\text { resources }\end{array}$} \\
\hline & & \multicolumn{2}{|c|}{ Data of 1960-1990 } & \multicolumn{2}{|c|}{ Data of 2004-2017 } & \\
\hline & & Reserves & Resources & Reserves & Resources & \\
\hline 1 & Albazinskoye & 12 & & 112 & 30 & $101-500$ \\
\hline 2 & Agnie-Afanasievskoye & 1.817 & $11.7^{1}$ & 0 & $70^{3}$ & $51-100$ \\
\hline 3 & Angochikanskoye & & & 0 & 0 & \\
\hline 4 & Belaya Gora & $4^{3}$ & 17 & $24^{7}$ & 35 & $51-100$ \\
\hline 5 & Blagodatnenskoye & & $5^{1}$ & 10 & $15^{7}$ & \\
\hline 6 & Delkenskoye & & $5^{4}$ & $42.5^{5}$ & 10 & $51-100$ \\
\hline 8 & Dyappe & 1.948 & $14.86^{2}$ & 7.6 & 40 & $101-500$ \\
\hline 9 & Zimovye & & 10 & & $12^{3}$ & $101-500$ \\
\hline 10 & Zolotaya Gora & & 27 & & $74^{7}$ & $51-100$ \\
\hline 11 & Kabachinskoye & & 24.7 & & $63^{7}$ & $51-100$ \\
\hline 12 & Kutynskoye & & $10^{3}$ & 6.6 & 24 & $51-100$ \\
\hline 13 & Limonitovoye & & $27^{3}$ & 0 & 0 & \\
\hline 14 & Polyanka & & $5^{3}$ & $17^{7}$ & 3 & $51-100$ \\
\hline 15 & Tarakanovskoye & & $5^{1}$ & 0 & 0 & \\
\hline \multicolumn{2}{|c|}{ Total for the area } & 15.765 & 162.26 & 219.7 & 376 & $>1500$ \\
\hline
\end{tabular}

Note: data - in italics Yu. I. Bakulin, 2004; bars ${ }^{1}$ - The Program on gold, $1996 ;{ }^{2}-$ M.K. Dyachkov, 1989; ${ }^{3}$ - V.Ya. Bespalov, 2006; ${ }^{4}$ - V.A. Kaidalov, 2008; ${ }^{5}$ - V.A. Filippov, 2012;

6- V.G. Vologin, 2014; ${ }^{7}$ - V.N. Priputnevich, 2014

\section{The results discussion}

As a result of the comparative analysis, 13 gold ore, 4 secondary quartzite, 13 porphyritic, 4 gold-tungsten, 1 polymetallic and 1 zeolitic bodies were identified as promising. The forecasts were tested in recommendations to the Khabarovsk Krai Government and subsoil users, as well as at various specialized conferences in the period 2007-2017.

The author's forecast formulations are confirmed by the geological study data of recent years. As a result of geological exploration work conducted from 2004 to 2014, eleven bodies (a table) of fifteen have been positively estimated within the Lower Amur area, studies continue on one of them, while on three - they have been stopped. The results of the geological study of recent years disprove the idea of low prospects for the objects, since very favorable data have been obtained on the territory high potential with reference to largevolume gold mineralization with moderate contents of the metal.

The table gives author's estimate for a number of areas. In this case, the facilities category by groups is designated subject to possible reserves (resources): 11-50; 51-100; 101500. Referring to a particular group is determined by zones' mineralization parameters. When a significant number of structural, morphological, metasomatic, geochemical factors 
coincided with the standards, the productivity of the standards was accepted, but in case of mismatch, the reduction coefficients were used with an interval of $25 \%$. A part of the mineral occurrences and deposits remains unrated since there are no reliable grounds to determine their ores' industrial type. Prospects of such mineral manifestations are unconditionally higher in comparison with the areas located outside the ore controlling structures.

\section{Conclusion}

Thus, the problem of the depletion of the mineral resources base of the 'old' ore regions in the Russian Far East can be resolved by revaluation their potential. On the example of the Lower Amur Region within which gold mining from ledge ores began as far back as the 19th century, opportunities for reassessing the potential of the territory are considered. Currently, the operation is continued at the Mnogovershinnoye deposit, while the Albazinskoye and Belogorskoye fields development has been started.

More than thirty deposits and gold mineralization and other metals, whose spatial position is subject to certain structural patterns, are distinguished as promising, within the Lower Amur area of gold mineralization. The orthogonal system of faults determines the position of the most promising bodies. A 'step' in the location of deposits is identified, equal to 15,30 and 60 kilometers. The standards of the near-surface (Belaya Gora), subvolcanic (Dyeppe) and hypabyssal (Zimovye) levels of mineralization are defined.

Among the selected facilities, Agnia-Afanasyevskoe, Blagodatnenskoye, Dylmenskoye, Dyappe, Kutynskoye, Uchaminskoye deposits are in the distributed fund. Within their limits, exploration work is currently under way. As a result of the geological study, the gold reserves of this territory increased from 15.7 tons to 219.7 tons (apart from reserves of the Mnogovershinnoye deposit). The rest of the deposits and mineral occurrences represent the non-distributed fund. The Lower Amur Region possesses real prospects for accumulation of the mineral resources base. It will allow planning the functioning of a mining and smelting enterprise in this ore mining area for a long period.

\section{References}

1. B.K. Mikhailov, B.I. Benevolskiy, S.S. Vartanyan, A.G. Volchkov, I.F. Migachev Subsoil exploration and protection. 9. p. 76-83. (2012).

2. A.V. Boyko, V.G. Vologin. Subsoil exploration and protection. 9, p. 39-43. (2012).

3. A.F. Chitalin, A.A. Efimov, K. I. Voskresenskiy, E. K. Ignatyev, A. G. Kolesnikov. Mineral resources of Russia. Economy and management. 3. p.65-69 (2013)

4. Bakulin Yu.I. Systematization of tin-bearing and gold-bearing ore systems for forecasting purposes/MG of the USSR, DVIMS (Far East Mineral Resources Institute). 'Nedra',. 192 p. (1991)

5. V.D. Melnikov

6. V.G. Moiseenko and L.V. Eirish. Gold-ore deposits of Russia's East. Vladivostok, 352 p. (1996).

7. N.P. Romanovskiy, Yu.F. Malyshev, Duan Zhuyan', Chzhu Tsun' and M. V. Goroshko. Pacific geology, 25 (6) P. 3-17. (2006).

8. V.I. Sukhov. Pacific geology, 19 (5). p. 5-20. (2006).

9. Khomich V.G. Metallogeny of volcano-plutonic belts of the northern link of AsianPacific interaction zone Vladivostok: Dalnauka, 1995. 343 p.

10. L.V. Eirish Pacific geology. 2. p. 67-80. 1991

11. V.L. Shevkalenko, collected papers Tectonics, the depth structure and geodynamics of Asia's east. III Kosygin readings. Khabarovsk, ITiG, p. 266-278. (2001). 